\title{
Developing Agreed and Accepted Understandings of Spirituality and Spiritual Care Concepts among Members of an Innovative Spirituality Interest Group in the Republic of Ireland
}

\author{
Fiona Timmins ${ }^{*}{ }^{\dagger}$, Maryanne Murphy ${ }^{\dagger}$, Sílvia Caldeira ${ }^{\dagger}$, Eimear Ging ${ }^{\dagger}$, Carole King ${ }^{\dagger}$, \\ Vivienne Brady ${ }^{\dagger}$, Jacqueline Whelan $^{\dagger},{ }^{\dagger}$ Colm O’ Boyle ${ }^{\dagger}$, John Kelly $^{\dagger}$, Freda Neill ${ }^{\dagger}$, \\ Geralyn Hynes ${ }^{\dagger}$, Kathleen Neenan ${ }^{\dagger}$, Nicolas Pujol $^{\dagger}{ }^{\dagger}$, Lisa Fitzgerald ${ }^{\dagger}$, Deborah Hayden ${ }^{\dagger}$, \\ Barbara Sweeney ${ }^{\dagger}$, Mary Threadgold ${ }^{\dagger}$, Michael $\mathrm{O}^{\prime}$ Sullivan ${ }^{\dagger}$, Bernadette Flanagan ${ }^{\dagger}$, \\ Elizabeth Weathers ${ }^{\dagger}$, Philip Larkin ${ }^{\dagger}$, Therese Meehan ${ }^{\dagger}$, Karen Ward ${ }^{\dagger}$, Hannah Chew ${ }^{\dagger}$, \\ Eunice Minford ${ }^{\dagger}$, Mandy Lee ${ }^{\dagger}$, Margaret Mulchaire ${ }^{\dagger}$, Anne Mc Auliffe $^{\dagger}$, P. J. Boyle ${ }^{\dagger}$, \\ Noel Keating ${ }^{\dagger}$ and Brian Nolan ${ }^{\dagger}$ \\ Spirituality Interest Group, School of Nursing and Midwifery, Trinity College Dublin, 24 D'Olier Street, \\ Dublin D02 T283, Republic of Ireland; MURPHM17@tcd.ie (M.M.); scaldeira@ics.lisboa.ucp.pt (S.C.); \\ EGing@STJAMES.IE (E.G.); cking2@tcd.ie (C.K.); bradyvi@tcd.ie (V.B.); whelanj1@tcd.ie (J.W.); \\ coboyle@tcd.ie (C.O.); John.Kelly@amnch.ie (J.K.); neillf@tcd.ie (F.N.); HYNESG2@tcd.ie (G.H.); \\ KANEENAN@tcd.ie (K.N.); pujolnicolas@ymail.com (N.P.); FITZGELI@tcd.ie (L.F.); dhayden@olh.ie (D.H.); \\ SWEENEBA@tcd.ie (B.S.); marythreadgold@hotmail.com (M.T.); spiremos@gmail.com (M.O.S.); \\ bflanagan@allhallows.ie (B.F.); e.weathers@ucc.ie (E.W.); philip.larkin@ucd.ie (P.L.); \\ Therese.Meehan@ucd.ie (T.M.); kward@iol.ie (K.W.); hannahchew@hotmail.com (H.C.); \\ euni.min@btinternet.com (E.M.); mslee@tcd.ie (M.L.); Margaret.Mulcaire@sjog.ie (M.M.); \\ A.McAuliffe@ucc.ie (A.M.A.); pj.boyle@hse.ie (P.J.B.); nkeating@eircom.net (N.K.); \\ bryan.nolan@hospicefoundation.ie (B.N.) \\ * Correspondence: timminsf@tcd.ie; Tel.: +353-1896-3699 \\ + These authors contributed equally to this work.
}

Academic Editor: Christine A. James

Received: 23 November 2015; Accepted: 2 March 2016; Published: 15 March 2016

Abstract: A Spirituality Interest Group (SIG) was set up in in the School of Nursing and Midwifery, Trinity College Dublin, Republic of Ireland (ROI), in March 2013. This paper reports on some of the journey and requirements involved in developing the group. It highlights the essential work of establishing agreed understandings in an objective way in order for the group to move forward with action. These agreed understandings have contributed to the group's success. Outlining the group's journey in arriving at agreements may be of use to others considering creating similar groups. One key action taken to determine the suitability of the group's aims and terms of reference was the distribution of a Survey Monkey to group members $(n=28)$ in 2014. One early meeting of the group discussed future goals and direction using the responses of this anonymous survey. This paper reports on the results of the survey regarding the establishment of the SIG and the development of a shared understanding of spiritual care among the members. There is consensus in the group that the spiritual care required by clients receiving healthcare ought to be an integrated effort across the healthcare team. However, there is an acceptance that spirituality and spiritual care are not always clearly understood concepts in practice. By developing shared or at least accepted understandings of spirituality and spiritual care, SIG hopes to be able to underpin both research and practice with solid foundational conceptual understanding, and in the process also to meet essential prerequisites for achieving the group's aims.

Keywords: spirituality; spiritual; spiritual care; interdisciplinary; health 


\section{Introduction}

This paper was presented at the First Spirituality Interest Group (SIG) International Conference of Spirituality in Healthcare held in Dublin in June 2015 [1]. It was presented as a case report on the development of a Spirituality Interest Group in the Republic of Ireland (ROI), but its main focus was on reporting the results of a survey of members that contributed towards the development of agreed conceptual understandings of spiritual care.

The need for the survey was motivated by the fact that despite widespread interest in spirituality and spiritual care in healthcare, these concepts are not always clearly delineated. By developing agreed understandings of spirituality and spiritual care, the group hoped to be able to underpin both research and practice with a solid conceptual foundation. SIG also felt that, given the breadth and complexity of the topic of spirituality, there was potential for the group itself to lose focus or become distracted, and so was attracted to carrying out the survey for the additional reason of assessing the cohesion of ideas and the relative importance of possible foci for a group gathering to promote spirituality.

The SIG's interest in the concept of spirituality reflects the unprecedented attention being given to the concept in the international healthcare literature [2,3]. An example of this growing interest in spirituality in the ROI was the international conference on Mental Health, Practical Theology, and Spirituality held at All Hallows College, Dublin City University (DCU) in June 2011 [4]. That conference was the first of its kind on the island of Ireland and two of its organising committee (B.F and M.O'S) are members of the SIG.

The ROI has a unique spiritual heritage. Historically, it has been a largely Roman Catholic (RC) country and, even with a decline in religious affiliation, $84.07 \%$ of Irish people still describe themselves as RC [5]. This high percentage is borne out by some hospital statistics that indicate a similar proportion of patients self-identifying as RC [6]. In view of this history, it is not surprising that the long-established hospital chaplaincy service that supports patients in healthcare also arose primarily from within the RC Church. Some, however, believe that the current service is still enshrined in this legacy $[7,8]$ and needs to be reviewed, given there is now a growing religious and ethnic diversity in Ireland $[8,9]$ with variant spiritual needs, including no particular faith [7]. Such diversity, they hold, requires that approaches to spiritual care in healthcare also need to change. There is concern that patients being admitted to hospital are not having their faith needs met and may be suffering personal consequences as a result [10]. However, there are also those who object to spiritual care and/or overt attention to particular faith needs being part of a contemporary healthcare service [7]. The SIG does not share that view. What drew its members together was the shared view that patients' spiritual needs in healthcare need to be addressed, and that, in an increasingly diverse and complex environment, healthcare staff may not be prepared for such a role.

SIG's position is supported by the expanding volume and scope of international literature that confirms nursing's and the wider healthcare community's interest in spirituality as a dimension of caring [11]. The Royal College of Nursing (RCN), the professional nursing body in the United Kingdom (UK), for example, has made recommendations for nurses' roles regarding patients' spiritual needs $[12,13]$. There is also some consensus internationally that patients' spiritual care requirements demand an integrated effort across the healthcare team [13]. Historically, spirituality has been an integral part of nursing and midwifery and its importance is still recognized by a continued emphasis on holistic healthcare [14,15]. Healthcare researchers differ, however, in how they integrate spirituality [14] within this holistic health paradigm, and concerns have been expressed about how spirituality may be interpreted in different healthcare settings internationally [16,17], including the conflation of spiritual with psychosocial care [18]. In short, internationally, spirituality is often loosely defined and interpreted in relation to religiosity and/or psychosocial care, but there has been little exploration of understandings of spirituality in the ROI setting. Nevertheless, the need for healthcare workers to address patients' spiritual needs is gaining momentum [19]. The need for nurses and midwives, for example, to provide spiritual care or contribute to the spiritual needs of the nation, is gaining increasing importance at local, national and even international nursing and midwifery policy 
level [20,21]. At the same time, Swinton and McSherry call for the nursing profession in particular to move beyond "official rhetoric" and "actually facilitate and enable meaningful spiritual care" for patients ([19], p. 801).

Existent curricular guidelines in the UK often firmly support the teaching of spiritual care to nurses by including this care aspect as one of the roles of the nurse [21]. This level of emphasis is lacking in the equivalent ROI guidelines [22]. However, even in the presence of recognition of the need for more guidance in the UK, the new NMC Code of Nursing Conduct [23] makes no reference to the spiritual dimension of healthcare [24]. While there is some agreement that spirituality needs to form part of the undergraduate curriculum, approaches vary and significant gaps exist in educational provision [24-29]. Internationally, there is a growing belief that professional nurses and midwives need direction regarding spiritual care [30]. Many international studies have found that nurses lack specific skills in spiritual assessment, awareness and referral opportunities [2] and this is also the case in the ROI [30]. While the nursing profession recognizes a role in the provision of spiritual care to patients [21], potential deficits in the provision of spiritual care to patients continues to be of concern $[30,31]$. These deficits relate to patients being discharged from hospital and reporting that their religious and/or spiritual needs were completely overlooked [10]. Furthermore, direction for nurses in both the UK and ROI is not very specific [20-22]. While developments are well documented in other parts of Europe and the USA [32], there is little published empirical work emerging within the domain of healthcare in the ROI. This paper reflects the growing interest in spirituality and spiritual care provision among healthcare practitioners and academics in the ROI. It describes an attempt by professional nurses and others to harness and develop this interest and thereby address the empirical deficit manifested in a lack of research in the field of spirituality and spiritual care.

The growing interest in spirituality and spiritual care provision is also linked with the rapid development of spirituality as an academic discipline in the past three to four decades [33,34]. There is also growing evidence to suggest that spiritual and/or religious support improves health outcomes [35]. Originally steeped in religious heritage, nursing and midwifery practice, like Western societies in general, has become increasingly secular [36]. And yet nurses' and midwives' consideration of patients' spiritual needs is now resurgent, both in the ROI and internationally [10,21,37]. However, it has been found in the ROI and internationally that nurses lack confidence and are underprepared to consider or address spiritual needs [2,31].

Over the past 20 years, nurses' attitudes worldwide toward the provision of spiritual care have been surveyed extensively, revealing that most are positively disposed to providing spiritual support [2,38-40]. Internationally, most nurses agree that they provide spiritual care as part of their nursing practice [29-31] although many are unprepared and may lack supporting education for the assessment or provision of such care [2,31]. The only study conducted in the ROI revealed similar findings [29]. With the exception of Turkish nurses in one study [38], most nurses see chaplains as a key resource for spiritual care [2,30]. Nonetheless, significant barriers exist to the provision of spiritual care or addressing of spiritual needs in healthcare practice. These barriers include lack of understanding of the concept of spirituality or recognition of its relevance for patients, uncertainty or discomfort about nurses' own personal spiritual or religious beliefs, embarrassment about the subject and lack of time [30].

In the ROI, a study conducted by the School of Ecumenics (TCD) [10] found that in Irish hospitals, patients' spiritual needs may not be met and that current approaches to chaplaincy may not cater to the increasing number of patients from non-Christian religions. Chaplains are often "brokering diversity", that is, addressing complex faith needs among patients with diverse cultural and religious beliefs ([40], p. 825).

Specific spiritual competencies for nurses are emerging [25-42] but, even though in the UK a systematic nursing assessment has been suggested [12,13], these competencies are not clearly articulated in either UK or ROI standards for the nursing and midwifery professions $[21,22]$ In the 
Netherlands, on the other hand, six core spiritual care competencies for nurses have been identified and these are commonly referred to within healthcare literature on the topic (Box 1).

Box 1. Six core competencies of spiritual nursing care are suggested by Van Leeuwen and Cusveller and colleagues [43-45].
(a) handling one's own beliefs,
(b) addressing spirituality,
(c) collecting spiritual assessment information,
(d) discussing and planning spiritual interventions,
(e) providing and evaluating spiritual care, and
$(f)$ integrating spirituality into institutional policy.

In the ROI, specific competencies in relation to spirituality have recently been identified for healthcare professionals working in palliative care [46]. Competencies relate to communication; optimising comfort and quality of life; care planning and collaborative healthcare practice; loss, grief and bereavement; and professional and ethical practice [46]. The authors also suggest a specific assessment of spiritual needs by chaplains and that spiritual "issues" be addressed by the multidisciplinary team ([46], p. 178). One recent international concept analysis carried out by Ramezani et al. [47] described the following specific attributes of spiritual care: "healing presence, therapeutic use of self, intuitive sense, exploration of the spiritual perspective, patient-centeredness, meaning-centred therapeutic intervention, and creation of a spiritually nurturing environment" ([47], p. 211).

There is agreement in the literature that nurses and midwives should have guidance to provide spiritual care [2,39]. They need adequate knowledge and skills to assist patients in identifying their spiritual needs and to ensure effective supports are in place. The nursing and midwifery professions, health provider organisations, and third-level educational settings have a role to play here. While there is agreement and concern that the required knowledge, training, and guidance are not optimal in many international settings, the situation is exacerbated in the ROI where little or no specific guidance around spiritual care is available for healthcare professions. Spirituality is particularly relevant in end-of-life care, older person care, trauma and intensive care, emergency department, [48] and in neonatal care [49] and maternity care settings [50]. What we need in the ROI is both development and implementation of national standards and guidelines regarding spiritual care that are related to a competence framework for all health and social care professionals working in areas of healthcare practice.

It was against this background of the need to address current deficits in healthcare practice and spiritual care delivery that the Spirituality Interest Group (SIG) was formed in the ROI. The group aims to act as a platform and to develop a greater understanding of the provision of spiritual care in healthcare. Its purpose is to develop the concept of spiritual care and to provide a space to promote, debate and discuss the role of spirituality in healthcare.

The group is self-financing, through research development funds and donations, and is supported by the SNM who provide space for its meetings and administrative support for public lectures and international conferences. This support has culminated in the SIG holding nine meetings, facilitating three visiting professors' visits, hosting 16 presentations and seven public lectures, and presenting the first SIG international spirituality in healthcare conference in the Republic of Ireland [1], with a second such conference planned for 23 June 2016. Three meetings are held annually across three university semesters and SIG membership is maintained by attending at least one meeting per year. In keeping with community engagement approaches and the need to engage with and include public and patients' perspectives, there is no requirement for participants to be health professionals. All tri-annual meetings are face to face. Each meeting so far has hosted 1-2 presentations by members on topics related to spirituality and/or spiritual care, followed by a structured meeting. Minutes for the meeting are recorded and circulated, and minute taking is rotational. An informal committee from the SNM plan and direct the meetings. The group is in its relative infancy and comprises members from various 
backgrounds (including psychology, social work, voluntary groups and medicine). While technologies are available that would facilitate virtual meetings, experience thus far demonstrates that members value the current format and there is good commitment to face-to-face meetings.

The group is situated within the "End of Life and Palliative Care in Malignancy and Non-Malignancy" research theme at the School [51]. Since its inception, SIG membership has grown from 17 in 2013 to 36 in 2015. Initially, membership mostly comprised staff from the SNM (82\%), but currently a slight majority (55\%) of the membership come from external bodies. The SIG group have links with the Centre for Spirituality Studies, University of Hull, UK and also obtained membership of the British Association for the Study of Spirituality, UK. Several projects have been performed under the auspices of the group including the development of a four-hour educational package for nurses and other healthcare workers [6], an audit of nursing textbooks [52], and a systematic review of the Experience of Spirituality from the Perspective of People Living with Dementia [53]. Members of the group have been involved in two European Committee of Science and Technology (COST) funding applications (2012 and 2014) related to the establishment of a European Spirituality Nursing and Midwifery Research Network led by Prof. Wilf McSherry [54] to aid the scientific exploration and advancement of spirituality and spiritual care. SIG members are also represented on the ROI HSE Healthcare Chaplaincy Professional Advisory Council (Chaplaincy Council) [55] and are currently undertaking a project entitled "An Exploration of Current Spiritual Care Resources in Health Care in the Republic of Ireland" [56]. A few SIG members also exercise leadership roles in the European Centre for the Academic Study of Christian Spirituality, which is hosted at the University of Zurich, the International Society for the Study of Christian Spirituality, which is linked to the American Academy of Religion, and the newly created Spirituality Institute for Research and Education (SpIRE) in Ireland. The SIG has their own logo (Figure 1), which was developed by one of the members (Lisa Fitzgerald) who drew on the group's ideas for the design.

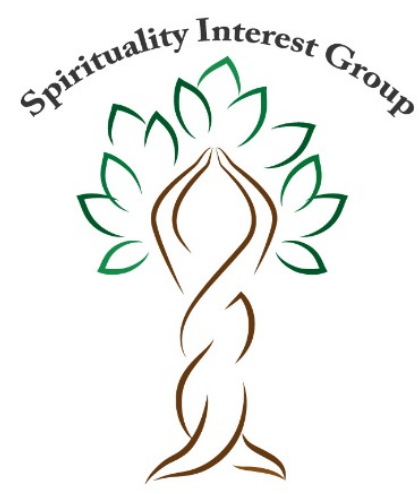

Figure 1. Spirituality Interest Group Logo ${ }^{\odot}$.

Consolidating agreed understandings of spirituality, spiritual care and also determining and agreeing to the groups' aim were deemed necessary for the group's progression. By developing agreed understandings of spirituality and spiritual care, the SIG hopes to be able to underpin both research and healthcare practice with a solid conceptual foundation. Without such clarity of key concepts there was concern that the group might lose focus or become distracted by peripheral issues. In July 2014, therefore, within six months of the group's inauguration, the views of the group were sought.

\section{The Approach}

\subsection{Aims}

A group survey was developed which aimed to collect data about the groups' views on definitions of spirituality and spiritual care and to confirm (or otherwise) the group's aims and terms of reference. 


\subsection{The Sample}

All members of SIG current at that time were invited to take part $(n=28)$. Given the very small size of the target population, a census was taken rather than utilizing a sampling approach, thus avoiding any sampling bias. Reminders were sent to participants after a two-week period. Seventeen participants took part in the survey in total, which represents a very healthy response rate $(60.7 \%)$ for an online survey.

\subsection{Data Collection Measures}

An online SurveyMonkey ${ }^{\mathrm{TM}}$ [57] was used to collect data about the group's views on definitions of spirituality and spiritual care, and also to confirm (or otherwise) the group's aims and terms of reference. The survey consisted of a series of closed and open-ended questions (21 items). Responses to closed items were either in yes/no format or respondents were invited to share their level of agreement with items using 5-point Likert scales. A "not applicable" option was also provided, to permit respondents to opt out if necessary, particularly when their expertise or experience did not permit them to comment. Open-ended items invited comments on the closed options to permit participants to expand on their responses.

\subsection{Ethical Considerations}

As this survey was for practice development/confirmatory audit purposes only, and was contained within a confined group for specific development purposes, ethical approval by the local College Research Ethics Committee (LCREC) was not deemed necessary. Conducting the survey and all of its associated elements was agreed at a formal SIG meeting, and elements of the survey were also agreed. The nature and purpose of the anonymous survey was explained on the first page, and all participants were required to tick a consent statement in order to take part in the survey. This consent statement formed part of the online survey and participants could not progress with survey completion without first consenting. The information page also explained that responses were both voluntary and anonymous, and the reporting of the findings in published format was a likely outcome. It was explained that no individuals would be identifiable through this process and that only aggregate data would be presented.

\section{Findings}

\subsection{SIG Aims, Terms of Reference and Future Goals}

Participants were asked the extent to which they agreed with the group's aims (Table 1 ) and terms of reference (Table 2).

Table 1. The extent to which the SIG members agree with the group's aims.

\begin{tabular}{|c|c|c|c|c|c|c|}
\hline $\begin{array}{l}\text { Outline the Extent to Which You } \\
\text { Agree with the Group's Aims. }\end{array}$ & $\begin{array}{l}\text { Strongly } \\
\text { Disagree }\end{array}$ & Disagree & Unsure & Agree & $\begin{array}{l}\text { Strongly } \\
\text { Agree }\end{array}$ & $\begin{array}{l}\text { Response } \\
\text { Count }\end{array}$ \\
\hline $\begin{array}{l}\text { To provide a platform to develop a } \\
\text { greater awareness of the need to } \\
\text { provide spiritual care. }\end{array}$ & 0 & 0 & 0 & $3(17.6 \%)$ & $14(82.4 \%)$ & 17 \\
\hline $\begin{array}{l}\text { To provide a platform to develop a } \\
\text { deeper understanding of the } \\
\text { concept of spiritual care. }\end{array}$ & 0 & 0 & 0 & $1(5.9 \%)$ & $16(94.1 \%)$ & 17 \\
\hline $\begin{array}{l}\text { To provide a space to promote, } \\
\text { debate and discuss the role of } \\
\text { spirituality in healthcare. }\end{array}$ & 0 & 0 & 0 & $1(5.9 \%)$ & $16(94.1 \%)$ & 17 \\
\hline
\end{tabular}


Table 2. The extent to which the SIG members agree with the group's terms of reference.

\begin{tabular}{|c|c|c|c|c|c|c|}
\hline $\begin{array}{l}\text { Outline the Extent to Which You } \\
\text { Agree with the Terms of Reference } \\
\text { Developed by the Group. }\end{array}$ & $\begin{array}{l}\text { Strongly } \\
\text { Disagree }\end{array}$ & Disagree & Unsure & Agree & $\begin{array}{l}\text { Strongly } \\
\text { Agree }\end{array}$ & $\begin{array}{l}\text { Response } \\
\text { Count }\end{array}$ \\
\hline $\begin{array}{l}\text { To raise awareness about providing } \\
\text { spiritual care in the healthcare context. }\end{array}$ & 0 & 0 & 0 & $3(17.6 \%)$ & $14(82.4 \%)$ & 17 \\
\hline $\begin{array}{l}\text { To develop, conduct and disseminate } \\
\text { research in the area of spirituality and } \\
\text { spiritual care related to health } \\
\text { and wellbeing. }\end{array}$ & 0 & 0 & 0 & $5(29.4 \%)$ & $12(70.6 \%)$ & 17 \\
\hline $\begin{array}{l}\text { To host discussions about the topic in } \\
\text { order to hear about the work and ideas } \\
\text { of others in the field, and contribute to } \\
\text { this debate. }\end{array}$ & 0 & 0 & 0 & $3(17.7 \%)$ & $14(82.4 \%)$ & 17 \\
\hline
\end{tabular}

Responses $(n=17,60 \%)$ revealed $100 \%$ agreement with the aims and terms of reference. The agreed terms of reference of SIG are to:

1. Raise awareness about spiritual care provision in the healthcare context;

2. Develop, conduct and disseminate research in the area of spirituality and spiritual care related to health and wellbeing;

3. Host discussions about the subject in order to understand the work and ideas of others in the field, and contribute further to this debate.

Further open-comment responses related to aims and terms of reference indicated the growing need for this type of group: "This is a neglected area in nursing" ([58], p. 2). Some members of the group were keen for the aims to include an influence on policy, which is catered for within SIG's long-term goals rather than directly in the aims/terms of reference:

There is a need to] make recommendations and inform future health policy, based on findings of research conducted by the group, i.e., ensuring that spirituality and spiritual wellbeing are recognized as important concepts across health institutions and amongst all healthcare professionals ([58], p. 5).

Participants were also asked the extent to which they agreed that the group's agreed short-term goals (12-18 months) (Table 3) and long-term goals (19-36 months) had been achieved (Table 4). Members' views on whether or not these latter long-term goals were realistic were also sought (Table 5).

Table 3. The extent to which SIG members agree that the short-term goals (12-18 months) of the group have been achieved.

\begin{tabular}{lccccccc}
\hline $\begin{array}{l}\text { To What Extent Do You Agree that } \\
\text { the Short-Term Goals (12-18 Months) } \\
\text { of the Group Were Achieved? }\end{array}$ & $\begin{array}{c}\text { Strongly } \\
\text { Disagree }\end{array}$ & Disagree & Unsure & Agree & $\begin{array}{c}\text { Strongly } \\
\text { Agree }\end{array}$ & $\begin{array}{c}\text { Not } \\
\text { Applicable }\end{array}$ & $\begin{array}{c}\text { Response } \\
\text { Count }\end{array}$ \\
\hline 3 meetings per year. & 0 & 0 & 0 & $7(43.7 \%)$ & $8(50 \%)$ & $1(6.3 \%)$ & 16 \\
\hline $\begin{array}{l}\text { Research and dissemination 1-2 } \\
\text { projects in the area. }\end{array}$ & 0 & 0 & $1(6.7 \%)$ & $8(53.3 \%)$ & $5(33.3 \%)$ & $1(6.7 \%)$ & 15 \\
\hline 3-4 invited speakers. & 0 & 0 & 0 & $8(53.3 \%)$ & $6(40 \%)$ & $1(6.7 \%)$ & 15 \\
\hline Link with School's research themes & 0 & 0 & $5(33.3 \%)$ & $4(26.7 \%)$ & $5(33.3 \%)$ & $1(6.7 \%)$ & 15 \\
\hline
\end{tabular}


Table 4. The extent to which SIG members agree that the long-term goals (19-36 months) of the group have been achieved.

\begin{tabular}{lcccccc}
\hline $\begin{array}{l}\text { To What Extent Do You Agree that the } \\
\text { Long-Term Goals (19-36 Months) of the } \\
\text { Group Have Been Achieved? }\end{array}$ & $\begin{array}{l}\text { Strongly } \\
\text { Disagree }\end{array}$ & Disagree & Unsure & Agree & $\begin{array}{c}\text { Strongly } \\
\text { Agree }\end{array}$ & $\begin{array}{c}\text { Response } \\
\text { Count }\end{array}$ \\
\hline Cohesive research plan related to 1-2 projects. & 0 & 0 & $2(11.8 \%)$ & $7(41.2 \%)$ & $8(47 \%)$ & 17 \\
Established PhD students. & 0 & 0 & $5(31.25 \%)$ & $6(37.5 \%)$ & $5(31.25 \%)$ & 16 \\
Contribute to policy. & 0 & 0 & $3(18.8 \%)$ & $4(25 \%)$ & $9(56.2 \%)$ & 16 \\
Possible standalone research pillar. & 0 & 0 & $6(35.3 \%)$ & $6(35.3 \%)$ & $5(29.4 \%)$ & 17 \\
Potential for centre of innovation. & 0 & $1(5.9 \%)$ & $5(29.4 \%)$ & $4(23.5 \%)$ & $7(41.2 \%)$ & 17 \\
\hline
\end{tabular}

Table 5. The extent to which SIG members agree that the long-term goals (19-36 months) of the group are realistic.

\begin{tabular}{|c|c|c|c|c|c|c|c|}
\hline $\begin{array}{l}\text { In Your View How Realistic Are the } \\
\text { Long-Term Goals (19-36 Months) of } \\
\text { the Group? }\end{array}$ & $\begin{array}{c}\text { Very } \\
\text { Unrealistic }\end{array}$ & $\begin{array}{l}\text { Somewhat } \\
\text { Realistic }\end{array}$ & Unsure & Realistic & $\begin{array}{l}\text { Extremely } \\
\text { Realistic }\end{array}$ & $\begin{array}{c}\text { Not } \\
\text { Applicable }\end{array}$ & $\begin{array}{l}\text { Response } \\
\text { Count }\end{array}$ \\
\hline $\begin{array}{l}\text { Cohesive research plan related to } \\
1-2 \text { projects. }\end{array}$ & 0 & $2(11.8 \%)$ & $3(17.7 \%)$ & $8(47 \%)$ & $3(17.7 \%)$ & $1(5.8 \%)$ & 17 \\
\hline Established PhD students. & 0 & $1(5.9 \%)$ & $6(35.3 \%)$ & $8(47 \%)$ & $1(5.9 \%)$ & $1(5.9 \%)$ & 17 \\
\hline Contribute to policy. & $1(6.3 \%)$ & 0 & $3(18.7 \%)$ & $11(68.7 \%)$ & 0 & $1(6.3 \%)$ & 16 \\
\hline
\end{tabular}

One participant suggested that it may be helpful to add "to develop international academic partnerships in the fields of spiritual care and spirituality \& health" to the terms of reference ([58], p. 2). Other than linking in with the School's research themes, all the short-term goals were deemed achieved (3 meetings per year, research and dissemination 1-2 projects in the area, 3-4 invited speakers). There was more uncertainty with long-term goals, although the majority agreed that there ought to be $1-2$ cohesive research projects emerging $(89 \%, n=15)$ and that the group should contribute to policy $(87 \%, n=13)$.

\subsection{Understandings of Spirituality}

Consensus on understandings of spirituality was also sought, as it was determined that a working definition of spirituality would be useful to the group. Suggestions were drawn from the literature on the topic and a recent concept analysis performed by one of the group members [59]. Spirituality was deemed to be that which gives life meaning, purpose and connection with others $(88 \%, n=15)$. All $(100 \%, n=17)$ agreed that spirituality is distinguished from religiosity but may incorporate religious beliefs for some people. Many respondents indicated that spirituality comprised a religious system of beliefs and values $(53 \%, n=9)$, or a nonreligious system of beliefs and values $(58 \%, n=13)$. The numbers who thought it comprised simply either or both are not clear from the survey. Some agreed that it was a metaphysical or transcendental phenomena $(47 \%, n=8)$. Most $(88 \%, n=15)$ agreed that spirituality is about connectedness, transcendence, and meaning and purpose in life. All agreed $(100 \%, n=17)$ with the overarching conceptual understanding [59] that addressing spiritual needs can result in alleviation of suffering, a sense of wellbeing, enhanced ability to adapt and cope with adversity, and a sense of peace and inner strength. However, there was uncertainty as to whether the prerequisites for spirituality [59] must include the presence of a belief system or worldview, the ability to take personal responsibility for care of spirit, and the ability to be accountable for daily life choices, with only over half agreeing $(53 \%, n=9)$ that these were necessary. Most agreed that spiritual care to clients in the healthcare setting is defined as providing care that takes into account the client's spirituality $(94 \%, n=16)$. Understandings of spiritual distress were also explored (Table 6). 
Table 6. Understandings of spiritual distress [60].

\begin{tabular}{|c|c|c|c|c|c|c|}
\hline Answer Options & $\begin{array}{l}\text { Strongly } \\
\text { Disagree }\end{array}$ & Disagree & Unsure & Agree & $\begin{array}{c}\text { Strongly } \\
\text { Agree }\end{array}$ & $\begin{array}{c}\text { Response } \\
\text { Count }\end{array}$ \\
\hline $\begin{array}{l}\text { The impaired ability to experience and } \\
\text { integrate meaning and purpose in life through } \\
\text { connectedness with self, others, art, music, } \\
\text { literature, nature, and/or a power greater } \\
\text { than oneself. }\end{array}$ & 0 & $2(11.8 \%)$ & $2(11.8 \%)$ & $10(58.8 \%)$ & $3(17.6 \%)$ & 17 \\
\hline $\begin{array}{l}\text { A state of suffering related to the impaired } \\
\text { ability to experience meaning in life through } \\
\text { connectedness with self, others, world or a } \\
\text { superior being (Caldeira et al. 2013) [60]. }\end{array}$ & 0 & $1(6.7 \%)$ & $5(33.3 \%)$ & $5(33.3 \%)$ & $4(26.7 \%)$ & 15 \\
\hline
\end{tabular}

Views on the activities that are relevant to the provision of spiritual care in healthcare settings were identified (Table 7) and the extent to which respondents believe that the competencies outlined by van Leeuwen and Cusveller (2004) [43] are required by nurses or midwives in healthcare settings was also explored (Table 8).

Table 7. Activities that are relevant to the provision of spiritual care in healthcare settings.

\begin{tabular}{lcccccc}
\hline \multicolumn{1}{c}{ Answer Options } & $\begin{array}{c}\text { Strongly } \\
\text { Disagree }\end{array}$ & Disagree & Unsure & Agree & $\begin{array}{c}\text { Strongly } \\
\text { Agree }\end{array}$ & $\begin{array}{c}\text { Response } \\
\text { Count }\end{array}$ \\
\hline $\begin{array}{l}\text { Providing care to clients that involves the } \\
\text { chaplain or pastoral care services. }\end{array}$ & 0 & $1(5.9 \%)$ & $1(5.9 \%)$ & $11(64.7 \%)$ & $4(23.5 \%)$ & 17 \\
\hline $\begin{array}{l}\text { Referring a client to the chaplain or pastoral } \\
\text { care services. }\end{array}$ & 0 & $1(5.9 \%)$ & $1(5.9 \%)$ & $12(70.6 \%)$ & $3(17.6 \%)$ & 17 \\
\hline $\begin{array}{l}\text { Providing a sacred space for clients, visitors } \\
\text { and staff. }\end{array}$ & 0 & 0 & $2(11.8 \%)$ & $10(58.8 \%)$ & $5(29.4 \%)$ & 17 \\
\hline $\begin{array}{l}\text { Providing clients access to religious services. } \\
\text { Providing clients with relief from suffering. }\end{array}$ & 0 & $\begin{array}{c}1(5.9 \%) \\
2(11.8 \%)\end{array}$ & $\begin{array}{l}2(11.8 \%) \\
2(11.8 \%)\end{array}$ & $\begin{array}{c}10(58.8 \%) \\
6(35.3 \%)\end{array}$ & $\begin{array}{l}4(23.5 \%) \\
7(41.1 \%)\end{array}$ & 17 \\
\hline
\end{tabular}

Table 8. The extent to which respondents believe that the competencies outlined by van Leeuwen and Cusveller (2004) [43] are required by nurses or midwives in healthcare settings.

\begin{tabular}{|c|c|c|c|c|c|c|}
\hline Answer Options & $\begin{array}{l}\text { Strongly } \\
\text { Disagree }\end{array}$ & Disagree & Unsure & Agree & $\begin{array}{c}\text { Strongly } \\
\text { Agree }\end{array}$ & $\begin{array}{l}\text { Response } \\
\text { Count }\end{array}$ \\
\hline Handling one's own beliefs & 0 & 0 & $1(5.9 \%)$ & $8(47 \%)$ & $8(47 \%)$ & 17 \\
\hline Providing and evaluating spiritual care & 0 & $1(5.9 \%)$ & $3(17.7 \%)$ & $7(41.1 \%)$ & $6(35.3 \%)$ & 17 \\
\hline Addressing spirituality & 0 & 0 & $1(5.9 \%)$ & $10(58.8 \%)$ & $6(35.3 \%)$ & 17 \\
\hline Collecting spiritual assessment information & 0 & $2(11.8 \%)$ & $2(11.8 \%)$ & $8(47 \%)$ & $5(29.4 \%)$ & 17 \\
\hline Discussing and planning spiritual interventions & 0 & $2(11.8 \%)$ & 0 & $10(58.8 \%)$ & $5(29.4 \%)$ & 17 \\
\hline
\end{tabular}

Participants were also asked for their views on spiritual assessment (Table 9) and their views on the personnel that have overall responsibility for the assessment of spiritual needs as a basis for the provision of spiritual care (Table 10).

Table 9. Views on approaches to spiritual assessment recommended in healthcare settings.

\begin{tabular}{ccc}
\hline Which of the Following Approaches to Spiritual Assessment Would You Recommend in Healthcare Settings? \\
\hline Answer Options & Response Percent & Response Count \\
\hline An assessment tool & $62.5 \%$ & 10 \\
Open-ended questions & $87.5 \%$ & 14 \\
Refer to chaplain/pastor & $50.0 \%$ & 8 \\
None & $0.0 \%$ & 0 \\
It's a personal matter and ought not to be addressed & $0.0 \%$ & 0 \\
No opinion & $0.0 \%$ & 0 \\
\hline
\end{tabular}


Table 10. Agreement on personnel that have overall responsibility for the assessment of spiritual needs as a basis for the provision of spiritual care.

\begin{tabular}{ccccccc}
\hline Answer Options & $\begin{array}{c}\text { Strongly } \\
\text { Disagree }\end{array}$ & Disagree & Unsure & Agree & $\begin{array}{c}\text { Strongly } \\
\text { Agree }\end{array}$ & $\begin{array}{c}\text { Response } \\
\text { Count }\end{array}$ \\
\hline Nurse & 1 & 1 & 0 & 12 & 2 & 16 \\
Medic/physician/doctor & 1 & 2 & 1 & 9 & 2 & 15 \\
Social worker & 1 & 1 & 3 & 5 & 3 & 13 \\
Chaplain/pastor & 1 & 1 & 2 & 7 & 4 & 15 \\
Volunteer & 1 & 4 & 2 & 3 & 2 & 12 \\
\hline
\end{tabular}

\subsection{Strategic Direction}

The group members were asked their views on the need to develop various strategies to progress the work of the SIG to develop spiritual awareness and care in healthcare practice. Most agreed that developing links with hospitals and hospices $(94 \%, n=16)$ and the community $(94 \%, n=16)$ represented the way forward. Most considered that an exploration of student nurses' and midwives' views of spirituality $(94 \%, n=16)$ would be useful and that it would be within the remit of the group to contribute to national developments in the field $(94 \%, n=16)$. However, there was less agreement as to whether or not a conclusive definition of spirituality $(53 \%, n=9)$, spiritual distress $(47 \%, n=8)$ or spiritual care $(53 \%, n=9)$ ought to be adopted. There was also little agreement as to whether a spiritual care strategy would aid the group to develop spiritual awareness and spiritual care in healthcare practice $(59 \%, n=10)$. The group was also not fully in agreement as to whether SIG needed a website to showcase the group's activities $(53 \%, n=9)$. A minority thought that linking with social networking sites $(47 \%, n=8)$ would be useful. Most agreed that addressing the issue of spirituality in healthcare might lead to organizational issues $(94 \%, n=16)$ and practical challenges $(100 \%, n=17)$, but these are not elaborated upon. It also has potential to raise ethical challenges $(88 \%, n=15)$. When asked about the skills and education perceived to be required to provide spiritual care in healthcare, responses focused on assessment, self-awareness and training skills:

1. "Increased self-awareness mindfulness and presence" ([58], p. 41);

2. "Self-awareness, empathy, sensitivity, listening skills. Training that addresses meaning, the concept of spirituality, spiritual care and needs and how to recognize, support and respond to suffering. Exploration of screening/assessment tools and practical use of same. Training in therapeutic relationships and communication" ([58], p. 41);

3. "Staff training in hospital sites. Undergraduate training for all allied health disciplines, nursing and medicine" ([58], p. 41);

4. "Communication skills are essential. Healthcare practitioners need to have some understanding of their own spirituality before they can be comfortable discussing spirituality with people they care for" ([58], p. 41).

\section{Discussion}

It is clear that spirituality and supporting peoples' spiritual needs is of concern across the wide range of disciplines that are represented within the group. The survey permitted the group members to consolidate their understandings of spirituality and spiritual care. It provided very clear direction on priorities across a large and diverse group.

The survey demonstrated the potential for agreed understandings of spirituality and spiritual care. This understanding is important to help the group to inform research but also to be able to articulate their mission and purpose. Given the variety of professional roles that members of the group hold, it is important that SIG retains a clear and independent identity that is not necessarily related to those roles. This does not present a conflict of interest, but rather demonstrates the importance of agreed understandings where diversity exists. There was also agreement (from the findings) to 
disagree, exemplified by the various opinions on whether or not spirituality incorporates religion. Indeed, the group has decided that the agreed understandings are operational definitions rather than fixed entities that could restrict the group.

The approach of developing agreed understandings among the group was very informative. It is reflective of a process described by Whitehead [61] as developing a living theory. Whitehead's work [61-63] promotes self-study as the basis for developing practice, and recommends the underpinning of professional practice by professional working theories. Whitehead's work promotes the notion and importance of exploring self to inform practice. On this basis, the group took the notion of exploring beliefs through a process of reflection (on oneself) to a small group (rather than individual) level. Rather than underpinning practice and professional theories by science, this approach suggested that it is underpinned by personal reflections on the world and on practice. This reflection, Whitehead believes, is a legitimate foundation for practice and practice development.

It is also important for a novel group such as this one to be focused in terms of research and development. While defining key terms is challenging and may only ever be provisional, it is also important that spirituality does not become a nebulous catchall concept [64]. The agreement on the extent of achievement of agreed goals is helpful for the group in terms of developing confidence. It is also useful to determine which long-term goals are more useful to the group. Informing national ROI policy, for example, is a key goal, whereas there is less certainty about supporting and developing $\mathrm{PhD}$ students. This again is possibly reflective of the diverse nature of the group's membership. At the same time, a group such as this, ultimately aiming to improve healthcare practice, needs to be responsive and mindful of people's views on the practicalities of approaches. The group's goals have been clarified and may now be viewed as short, middle and long-term. Short-term goals involved clarity of concepts, missions and goals, relationships with national and international groups, and have largely been achieved. Middle-term goals centre around improving and implementing 2-3 research projects, possibly by involving undergraduate, master's and PhD students in research and developing a standalone research strand in the SNM. Long-term goals include continuing with the research and contributing to national ROI policy. However, the idea of developing a centre of innovation has been determined as unrealistic at present.

The survey findings also determined various strategies to progress the work of the SIG including developing links with hospitals and hospices and the community. There was also a strong belief that spiritual assessment forms a key part of healthcare practice, so developing some research and/or practice in this area may be useful. Regarding developing a way forward for the group that will both sustain interest and develop the research agenda, it is important now to secure funding to bring expertise to support the group and its initiatives, and to develop substantive research projects. Guidance in determining the best way forward for the group is crucial, as is networking and gaining support from international colleagues in the field.

A strong bond has developed within the group that appears, anecdotally at least, to be nurturing to participants. While this was not SIG's initial intention, it is a positive outcome.

\section{Conclusions}

The group has grown considerably in size and cohesion since its inception, and the development of accepted understandings, facilitated by this survey, has been crucial to the group's development. The group membership and large numbers (up to 100 people) attending each one of its public lectures are a testament to the interest that exists in the area. As the literature suggests, there appears to be a widespread interest in spirituality alongside a general sense of unpreparedness, possibly related to confusion about the term and roles when addressing it in practice.

Looking forward, SIG hopes to contribute to improving practitioners' knowledge and awareness of the importance of spirituality in practice. It is developing a focused research agenda and has already contributed to national policy in an active way. SIG also aims to develop a standalone research theme in the SNM. It also aims to link research endeavours in the ROI through relationships and involvement 
with the newly developed Spirituality Institute for Research and Education (SpIRE). The unique historical challenges of developing the academic study of spirituality in the ROI have been discussed elsewhere. It is important to publish information on activities such as those in which this SIG group is engaged and important for like-minded readers to hear about how academics, researchers, and providers across the globe are reintroducing spirituality into academic and healthcare settings.

\section{Limitations}

The approach is limited by its small convenience sampling and self-study approach. However, as the survey's purpose was to collate a vision among the group for this specific purpose, it was appropriate. Additionally, in keeping with approaches to self-study [61,62], the small specific sampling is wholly acceptable for developing living practice theories.

Acknowledgments: The authors would like to thank the School of Nursing and Midwifery Trinity College Dublin who accommodate the Spirituality Interest Group, and all of the members and speakers who have given so freely of their time. SIG would like to acknowledge the kind support of Jeni Ryan, BA MA, Administrative Office, Conference Organizer, School of Nursing and Midwifery, Trinity College Dublin who supported the organization and management of the first SIG conference [1]. Michael O'Sullivan is also a Research Fellow, Department of New Testament, University of the Free State, Bloemfontein 9300, South Africa.

Author Contributions: Fiona Timmins conceived and initiated SIG. Carole King, Maryanne Murphy, Vivienne Brady and Jacqueline Whelan developed SIG and its processes. They manage SIG and organized the first SIG conference [1]. Fiona Timmins designed the survey, distributed it and collected and analyzed the data. Fiona Timmins, Maryanne Murphy, Sílvia Caldeira, Eimear Ging, Carole King, Vivienne Brady, Jacqueline Whelan, Colm O’Boyle, John Kelly, Freda Neill, Geralyn Hynes, Kathleen Neenan, Nicolas Pujol, Lisa Fitzgerald, Deborah Hayden, Barbara Sweeney, Mary Threadgold, Michael O'Sullivan, Bernadette Flanagan, Elizabeth Weathers, Philip Larkin, Therese Meehan, Karen Ward, Hannah Chew, Eunice Minford, Mandy Lee, Margaret Mulchaire, Anne Mc Auliffe, P.J. Boyle, Noel Keating, and Brian Nolan contributed to the ongoing practical and conceptual development of SIG, including deliberation on terms of reference and definitions. They also contributed to the survey's development and design and took part in the survey. They agreed on the paper's content. Lisa Fitzgerald designed the SIG logo and provided valuable contributions to the SIG conference, including poster design, twitter feed, website design and marketing. Fiona Timmins wrote and finalized the paper. Maryanne Murphy, Sílvia Caldeira, Eimear Ging and Colm O'Boyle revised initial versions of the paper for academic content. All authors provided valuable written comments and feedback on drafts of the paper. Fiona Timmins, Michael O'Sullivan, Silvia Caldeira and Colm O'Bolye finalised the paper for publication.

Conflicts of Interest: The authors declare no conflict of interest.

\section{Abbreviations}

The following abbreviations are used in this manuscript:

$\begin{array}{ll}\text { ABA } & \text { An Bord Altranais (Nursing Board of Ireland) now called the National Nursing and Midwifery } \\ & \text { Board of Ireland (NMBI) } \\ \text { DCU } & \text { Dublin City University } \\ \text { NMC } & \text { National Nursing and Midwifery Council (UK) } \\ \text { ROI } & \text { Republic of Ireland; RCN: Royal College of Nursing (UK) } \\ \text { SIG } & \text { Spirituality Interest Group, Dublin, Ireland } \\ \text { SNM } & \text { School of Nursing and Midwifery (Trinity College Dublin) } \\ \text { TCD } & \text { Trinity College Dublin } \\ \text { UK } & \text { United Kingdom } \\ \text { WHO } & \text { World Health Organisation }\end{array}$

\section{References}

1. Spirituality Interest Group. "First International Conference of Spirituality in Healthcare held in Dublin." Sowing the Seeds, 2015. Available online: http://nursing-midwifery.tcd.ie/events-conferences / sowingtheseeds_conf2015.php (assessed on 3 October 2015).

2. Wilfred McSherry, and Steve Jamieson. "An online survey of nurses' perceptions of spirituality and spiritual care." Journal of Clinical Nursing 20 (2011): 1757-67. [CrossRef] [PubMed] 
3. John Cullen. "Nursing management, religion and spirituality: A bibliometric review, a research agenda and implications for practice." Journal of Nursing Management 2015. Published electronically 26 October 2015. [CrossRef] [PubMed]

4. "A Conference: Mental Health, Practical Theology and Spirituality." 10 June 2011. Available online: http:/ / www.allhallows.ie/wp-content/uploads/2013/06/A-Conference-Mental-Health-Practical-TheologySpirituality-June-2011.pdf (accessed on 23 September 2015).

5. Central Statistics Office. “Census 2011 Results: Profile 7 Religion, Ethnicity and Irish Travellers—Ethnic and cultural background in Ireland." Available online: http://www.cso.ie/en/media/csoie/census/ documents/census2011profile7/Profile,7,Press,Release,Religion,,Ethnicity,and,Irish,Travellers.pdf (accessed on 31 March 2015).

6. Fiona Timmins, Freda Neill, Mary Quinn-Griffin, John Kelly, and Eden De La Cruz. "Spiritual Dimensions of Care: Developing an Educational Package for Nurses in the Republic of Ireland." Holistic Nursing Practice 28 (2014): 106-23. [CrossRef] [PubMed]

7. Humanist Association of Ireland. "Submission to HSE on Chaplaincy Services September 2013." Available online: http:/ /humanism.ie/2015/02/submission-to-hse-on-chaplaincy-services-september-2013/ (accessed on 3 April 2015).

8. Health Service Executive. A Question of Faith-The Relevance of Faith and Spirituality in Health Care. Dublin: Health Service Executive, 2011.

9. Central Statistics Office. "Persons usually resident and present in the state on census night, classified by place of birth and age group." 2011. Available online: http://www.cso.ie/multiquicktables/quick Tables.aspx?id=cdd22 (accessed on 31 March 2015).

10. Katy Radford. Health, Faith and Equality Prepared for the Health Research Board through Building Partnerships for Healthier Society Research Award. Dublin: Health Research Board/Irish School of Ecumenics, 2008.

11. Juliet Rothman. "Spirituality: What we can teach and how we can teach it?" Journal of Religion E Spirituality in Social Work 28 (2009): 161-84. [CrossRef]

12. Royal College of Nursing. RCN Spirituality in Nursing Care: A Pocket Guide. London: RCN, 2011.

13. "Royal College of Nursing Spirituality in nursing care: Online resource introduction." Available online: http://www.rcn.org.uk/development/practice/spirituality/about_spirituality_in_nursing_care (accessed on 22 September 2015).

14. Lisa Burkhart, and Nancy Hogan. "An experiential theory of spiritual care in nursing practice." Qualitative Health Research 18 (2008): 928-38. [CrossRef] [PubMed]

15. Ann Bradshaw. "Spiritual care: The legacy of Nightingale." Nursing Times 92 (1996): 42-43. [PubMed]

16. John Swinton. "Identity and resistance: Why spiritual care needs 'enemies'?" Journal of Clinical Nursing 15 (2006): 918-28. [CrossRef] [PubMed]

17. Par Salander. "Who needs the concept of 'spirituality'?" Psychooncology 15 (2006): 647-49. [CrossRef] [PubMed]

18. King, M. "The challenge of research into religion and spirituality." Journal for the Study of Spirituality 4 (2014): 106-20. [CrossRef]

19. John Swinton, and Wilfred McSherry. "Editorial: Critical reflections on the state of spirituality in nursing." Journal of Clinical Nursing 15 (2006): 801-2. [CrossRef]

20. Nursing and Midwifery Council. The Code: Standards of Conduct, Performance and Ethics for Nurses and Midwives. London: Nursing and Midwifery Council, 2008.

21. Nursing and Midwifery Council. "Standards of proficiency for pre-registration nursing education 2010." Available online: https://www.nmc.org.uk/standards/additional-standards/standards-for-pre-registrationnursing-education/ (accessed on 22 September 2015).

22. An Bord Altranais (ABA). Requirements and Standards for Nurse Registration Education Programmes. Dublin: An Bord Altranais, 2005.

23. "Nursing and Midwifery Council." Available online: http://www.nmc.org.uk/standards/code/ (accessed on 22 September 2015).

24. Wilfred McSherry. "How relevant is spirituality to patient-centred care?" Nursing Times 111 (2015): 23. [PubMed]

25. Wilfred McSherry. Making Sense of Spirituality in Nursing Practice, 2nd ed. London: Jessica Kingsley, 2008. 
26. Lesline P. Lewinson, Wilfred McSherry, and Peter Kevern. "Spirituality in pre-registration nurse education and practice: A review of the literature." Nurse Education Today 35 (2015): 806-14. [CrossRef] [PubMed]

27. Donia Baldacchino. "Teaching on the spiritual dimension in care: The perceived impact on undergraduate nursing students." Nurse Education Today 28 (2008): 501-12. [CrossRef] [PubMed]

28. Donia Baldacchino. "Teaching on the spiritual dimension in care to undergraduate nursing students: The content and teaching methods." Nurse Education Today 28 (2008): 550-62. [CrossRef] [PubMed]

29. Suzette Brémault-Phillips, Joane Olson, Pamela Brett-MacLean, Doreen Oneschuk, Shane Sinclair, Ralph Magnus, Jeanne Weis, Marjan Abbasi, Jasneet Parmar, and Christina Puchalski. “Integrating Spirituality as a Key Component of Patient Care." Religions 6 (2015): 476-98. [CrossRef]

30. Fiona Timmins. "Nurse's Views of Spirituality and Spiritual Care Provision in the Republic of Ireland." Journal for the Study of Spirituality 3 (2013): 121-37. [CrossRef]

31. Wilfred McSherry, Keith Cash, and Linda Ross. "Meaning of Spirituality: Implications for Nursing Practice." Journal of Clinical Nursing 13 (2004): 934-41. [CrossRef] [PubMed]

32. Mark Cobb, Christina Puchalski, and Bruce Rumbold. Oxford Textbook of Spirituality in Healthcare. Oxford: Oxford University Press, 2012.

33. Michael O'Sullivan. “Spirituality_A New Academic Discipline." Melita Theologica 59 (2008): 71-77.

34. Michael O'Sullivan. Spiritual Capital and the Turn to Spirituality. In Spiritual Capital—Spirituality in Practice in Christian Perspective. Edited by Michael O'Sullivan and Bernadette Flanagan. Farnham: Ashgate, 2012, pp. 43-59.

35. Harold G. Koenig. "Commentary: Why Do Research on Spirituality and Health, and What Do the Results Mean?" Journal of Religion and Health 51 (2012): 460-67. [CrossRef] [PubMed]

36. John Paley. "Spirituality and secularization: Nursing and the sociology of religion." Journal of Clinical Nursing 17 (2008): 175-86. [CrossRef] [PubMed]

37. World Health Organisation. "Spirituality and health: An initial proposal to incorporate spiritual health in health impact assessment." 2012. Available online: http://www.who.int/hia/examples/overview/ whohia203/en/ (accessed on 22 September 2015).

38. Ferda Ozbasaran, Safak Ergul, Ayla B. Temel, Gulsah G. Aslan, and Ayden Coban. "Turkish nurses' perceptions of spirituality and spiritual care." Journal of Clinical Nursing 20 (2011): 3102-10. [CrossRef] [PubMed]

39. Pranee C. Lundberg, and Petcharat Kerdonfag. "Spiritual care provided by Thai nurses in intensive care units." Journal of Clinical Nursing 19 (2010): 1121-28. [CrossRef] [PubMed]

40. Mikael Lundmark. "Attitudes to spiritual care among nursing staff in a Swedish oncology clinic." Journal of Clinical Nursing 15 (2006): 863-74. [CrossRef] [PubMed]

41. Barbara Pesut, Sheryl Reimer-Kirkham, Richard Sawatzky, Gloria Woodland, and Perry Peverall. "Hospitable Hospitals in a Diverse Society: From Chaplains to Spiritual Care Providers." Journal of Religion and Health 51 (2012): 825-36. [CrossRef] [PubMed]

42. Josephine Attard, Donia Baldacchino, and Liberato Camilleri. “Nurses' and midwives' acquisition of competency in spiritual care: A focus on education." Nurse Education Today 34 (2014): 1460-66. [CrossRef] [PubMed]

43. René van Leeuwen, and Bart Cusveller. "Nursing competencies for spiritual care." Journal of Advanced Nursing 48 (2006): 234-46. [CrossRef] [PubMed]

44. René van Leeuwen, Lucas Tiesinga, Doeke Post, and Henk Jochemsen. "Spiritual care: Implications for nurses' professional responsibility." Journal of Clinical Nursing 15 (2006): 875-84. [CrossRef] [PubMed]

45. René van Leeuwen, Lucas Tiesinga, Berrie Middel, Doeke Post, and Henk Jochemsen. “An Instrument to measure nursing Competencies in Spiritual Care: Validity and reliability of the Spiritual Care Competence Scale (SCCS)." Journal of Clinical Nursing 18 (2009): 2857-69. [CrossRef] [PubMed]

46. Palliative Care Competence Framework Steering Group. Palliative Care Competence Framework. Dublin: Health Service Executive, 2014.

47. Monir Ramezani, Fazlollah Ahmadi, Eesa Mohammadi, and Anoshirvan Kazemnejad. "Spiritual care in nursing: A concept analysis." International Nursing Review 61 (2014): 211-19. [CrossRef] [PubMed]

48. Harold G. Koenig. "The Spiritual Care Team: Enabling the Practice of Whole Person Medicine." Religions 5 (2014): 1161-74. [CrossRef] 
49. Christopher Newell, and Lindsay B. Carey. “Economic Rationalism and the Cost Efficiency of Hospital Chaplaincy: An Australian Study." Journal of Health Care Chaplaincy 10 (2000): 37-52. [CrossRef] [PubMed]

50. Daniel Nuzum, Sarah Meaney, and Keelin O'Donoghue. "The provision of spiritual and pastoral care following stillbirth in Ireland: A mixed methods study." BMJ Supportive and Palliative Care 2014. Published electronically 10 June 2014. [CrossRef] [PubMed]

51. School of Nursing and Midwifery. "Palliative Care." 2015. Available online: http://nursing-midwifery. tcd.ie/research/groups/palliative-care.php (accessed on 15 October 2015).

52. Fiona Timmins, Marianne Murphy, Freda Neill, Cecily Begley, and Greg Sheaf. "An exploration of the extent of inclusion of spirituality and spiritual care concepts in core nursing textbooks." Nurse Education Today 35 (2015): 277-82. [CrossRef] [PubMed]

53. Louise Daly, Fahey McCarthy, and Fiona Timmins. "Spirituality and dementia: The perspective of people with dementia." Paper presented at the 5th International Nursing and Midwifery Conference, NUIG School of Nursing and Midwifery, Galway, Republic of Ireland, 30 May 2015.

54. Staffordshire University. Available online: http://www.staffs.ac.uk/staff/profiles/wm4.jsp (accessed on 18 November 2015).

55. Health Services Executive in the ROI (HSE). The Organisation of Chaplaincy Services in the HSE-Multi-Faith Healthcare Chaplains Group/Council. Dublin: HSE, 2014.

56. Fiona Timmins, Marianne Murphy, Nicolas Pujol, Greg Sheaf, Sílvia Caldeira, Jacqueline Whelan, Elizabeth Weathers, and Bernadette Flanagan. An Exploration of Current Spiritual Care Resources in Health Care in the Republic of Ireland (ROI). Dublin: Trinity College Dublin, 2013.

57. Survey Monkey. Available online: https://www.surveymonkey.net (accessed on 21 November 2015).

58. Fiona Timmins. Spirituality Interest Group Survey. Dublin: Trinity College Dublin, 2014.

59. Elizabeth Weathers, Geraldine McCarthy, and Alice Coffey. "Concept analysis of spirituality: An evolutionary approach." Nursing Forum. Available online: http:/ / onlinelibrary.wiley.com/doi/10.1111/nuf.12128/epdf (accessed on 18 November 2015).

60. Sílvia Caldeira, Emília C. Carvalho, and Margarida Vieira. "Spiritual distress-Proposing a new definition and defining characteristics." International Journal of Nursing Knowledge 24 (2013): 77-84. [CrossRef] [PubMed]

61. Jack Whitehead. "Jack Whitehead's ontological commitments in self-study: The transformative potential of individuals' collaborative self-studies for sustainable global educational networks of communication." Paper presented at the AERA 2004 Symposium of the Self-Study in Teacher Education Practices, San Diego, CA, USA, 16 April 2004.

62. Jack Whitehead. "How do I Improve my Practice? Creating a Discipline of Education through Educational Enquiry." Ph.D. Thesis, University of Bath, Bath, UK, 1999. Available online: http://www. actionresearch.net/writings/phdok.pdf (accessed on 14 January 2016).

63. Jack Whitehead. “Living Theory Masters and Dissertations." 2016. Available online: http://www. actionresearch.net/living/living.shtml (accessed on 14 January 2016).

64. Joanna Byrant. "Assertion and assumption: A single site study of acute healthcare chaplaincy." Unpublished Master's Degree Thesis, University of Birmingham, Birmingham, UK, 2013. Available online: http:/ /etheses. bham.ac.uk/4973/1/Bryant14MRes.pdf (accessed on 13 November 2015).

(C) 2016 by the authors; licensee MDPI, Basel, Switzerland. This article is an open access article distributed under the terms and conditions of the Creative Commons by Attribution (CC-BY) license (http://creativecommons.org/licenses/by/4.0/). 